\title{
Reclassification of Brevibacterium leucinophagum Kinney and Werkman as a Gram-Negative Organism, Probably in the Genus Acinetobacter
}

\author{
DOROTHY JONES and P. DAVID J. WEITZMAN
}

\begin{abstract}
M. R. C. Microbial Systematics Unit and Department of Biochemistry, School of Biological Sciences, Leicester University, Leicester, England
\end{abstract}

\begin{abstract}
A study of the tricarboxylic acid cycle enzymes of Brevibacterium leucinophagum ATCC 13809, the type strain of this species, together with morphological, physiological, and electron microscopy studies indicated that, contrary to its present classification, $B$. leucinophagum is gram negative and probably is better classified in the genus Acinetobacter.
\end{abstract}

A previous study of 50 strains of bacteria, including gram-negative and gram-positive species, indicated a clear correlation between their taxonomic grouping and the regulatory properties of their citrate synthases (13). Citrate synthases from gram-negative bacteria were inhibited by reduced nicotinamide adenine dinucleotide (NADH), and in strictly aerobic species this inhibition was overcome by adenosine 5'-monophosphate (AMP). Subsequent studies (12) of the molecular sizes of these different enzymes showed citrate synthases of gram-negative bacteria to be "large" (molecular weight 200,000 to 300,000 ), whereas the enzymes from gram-positive bacteria were "small" (molecular weight $<100,000$ ). Investigations on other enzymes of the tricarboxylic acid cycle have shown that, in acinetobacters and certain other gram-negative aerobes, pyruvate dehydrogenase, isocitrate dehydrogenase, $\alpha$-ketoglutarate dehydrogenase and succinate thiokinase participate with citrate synthase in an extensive "multipoint" control of the activity of the cycle by the adenylate system (P. D. J. Weitzman, in press).

During an investigation of the genus Brevibacterium, we examined ATCC 13809, the type strain of Brevibacterium leucinophagum Kinney and Werkman (4), which was described by these authors as a gram-positive bacterium which frequently becomes gram-negative after 12 to $13 \mathrm{~h}$. However, our studies of the citrate synthase of $B$. leucinophagum suggested that this organism is not gram positive and prompted us to examine the other tricarboxylic acid cycle enzymes. In addition we rechecked the cultural, morphological, and physiological characters of this organism.

\section{MATERIALS AND METHODS}

Strains. The following organisms were used: Brevibacterium leucinophagum ATCC 13809; Brevibacterium linens ATCC 9174; Acinetobacter lwoffi NCTC 5867; $A$. lwoffi strain 4B, identified by S. P. Lapage; Acinetobacter anitratus NCTC 8102; and Pseudomonas aeruginosa NCIB 8295. All cultures were maintained on nutrient agar (Oxoid) at $30 \mathrm{C}$ and were preserved by freeze-drying.

Tests. Cultural, morphological, and physiological tests with $B$. leucinophagum were performed by the methods of Kinney and Werkman (4) and Thornley (8). Sensitivity to penicillin was determined by lawning a 24-h culture of $B$. leucinophagum onto blood agar base medium (Oxoid) and immediately placing on the plate a high-potency penicillin disk (Sentests, Evans Medical Ltd., Liverpool). The test was read after incubation for $24 \mathrm{~h}$ and $48 \mathrm{~h}$ at $30 \mathrm{C}$.

Preparation of cells and cell-free extracts. All cultures were grown aerobically in nutrient broth (Oxoid) for $24 \mathrm{~h}$ at $30 \mathrm{C}$. The cells were collected by centrifugation at $25,000 \times g$ for $10 \mathrm{~min}$, washed with buffer of composition $20 \mathrm{mM}$ tris(hydroxymethyl) aminomethane-hydrochloride, $\mathrm{pH} 8.0,10 \mathrm{mM} \mathrm{MgCl}_{2}$, and $1 \mathrm{mM}$ ethylenediaminetetraacetic acid, and disrupted by ultrasonic treatment in an M.S.E. 100-W sonicator for $2 \mathrm{~min}$ at full power with cooling. After recentrifugation, the supernatant solutions were used without further purification.

Enzyme studies. Measurements of citrate synthase activity and of the effects of NADH and AMP were carried out spectrophotometrically at $412 \mathrm{~nm}$ as previously described (13). The dehydrogenases were assayed spectrophotometrically at $340 \mathrm{~nm}$ under conditions previously reported: isocitrate dehydrogenase (5), $\alpha$-ketoglutarate dehydrogenase, and pyruvate dehydrogenase (11), using $1 \mathrm{mM} \alpha$-ketoglutarate or $1 \mathrm{mM}$ pyruvate, respectively. The three dehydrogenases were tested for AMP stimulation by including $1 \mathrm{mM}$ AMP in the assays. Succinate thiokinase was assayed by a polarographic procedure 
(10) which monitors the appearance of coenzyme $A$ at a dropping mercury electrode at $-0.3 \mathrm{~V}$. Reaction mixtures contained $0.1 \mathrm{M}$ phosphate buffer, $\mathrm{pH} 8.0$, $10 \mathrm{mM} \mathrm{MgCl}$, and $0.1 \mathrm{mM}$ succinyl-coenzyme $A$, and the adenosine diphosphate (ADP) concentration was varied to obtain an approximate $K_{m}$ value for this substrate. $K_{m}$ values could be classified as either "high" ( $\sim 1 \mathrm{mM})$ or "low" ( 0.02 mM).

The molecular sizes of citrate synthases were determined by gel filtration on Sephadex G-200 using catalase (beef liver, $2 x$ crystallized, Sigma Chemical Co., Kingston-upon-Thames, England) and lactate dehydrogenase (rabbit muscle, The Boehringer Corp., Ltd., London) as marker proteins (12). Large citrate synthases were eluted before catalase and small enzymes were eluted after lactate dehydrogenase.

Electron microscopy. ATCC 13809 was grown in $500 \mathrm{ml}$ of nutrient broth (Oxoid) for $48 \mathrm{~h}$ at $30 \mathrm{C}$. The growth was harvested by centrifugation at 25,000 $X g$ for $10 \mathrm{~min}$. The pellet was resuspended in $20 \mathrm{ml}$ of growth medium and prefixed in glutaraldehyde, fixed with osmium tetroxide, embedded in agar, and finally dehydrated in ethanol and embedded in araldite as described by Glauert and Thornley (2). Thin sections were cut on an LKB ultratome equipped with a glass knife. These sections were collected on 300-mesh copper grids coated with Formvar, stained for $30 \mathrm{~min}$ with the undiluted lead citrate stain of Reynolds (7), and examined in a Siemens Elmiscop 1A electron microscope.

\section{RESULTS AND DISCUSSION}

The results of the examination of the tricarboxylic acid cycle enzymes are presented in Table 1. For comparative purposes, the results obtained with $A$. lwoffi, $P$. aeruginosa, and $B$. linens are included. The citrate synthase of $B$. leucinophagum is of the large type and is inhibited by NADH; this inhibition is overcome by AMP. These results indicate that $B$. leucinophagum is an aerobic, gram-negative bacterium (cf. Weitzman and Jones [13]). Furthermore, the reactions of other tricarboxylic acid cycle enzymes listed in Table 1 suggest that $B$. leucinophagum is very similar to $A$. Iwoffi (5, 11).

The results of the cultural, morphological, and physiological tests with $B$. leucinophagum were in good agreement with the findings of Kinney and Werkman (4), who first described this organism, except for the reaction to the Gram stain, the ability to utilize lactose and mannose oxidatively, and the slow urease activity. In our hands this organism was never found to be frankly gram positive but was gram negative with traces of gram-positive staining. Consistent with the abovementioned results, $B$. leucinophagum was found to be resistant to the action of penicillin (Table 2). Additionally, an electron micrograph of a thin section of the cell wall indicated a gram-negative structure; that is, the cell contained an outer membrane, a dense intermediate layer, and a plasma membrane (Fig. 1).

The reaction to the Gram stain is usually unequivocal, and most bacteria can be easily assigned to one of the two major divisions. However, there are bacteria which give equivocal Gram staining reactions and, because of this, are often placed in an unsuitable genus. For example, ATCC 15716 was placed in the genus

TABLE 1. Characteristics of selected enzymes from Brevibacterium leucinophagum ATCC 13809 and certain other bacteria

\begin{tabular}{l|c|c|c|c}
\hline \multicolumn{1}{c|}{ Characteristic } & $\begin{array}{c}\text { Brevibacterium } \\
\text { leucinophagum } \\
\text { ATCC 13809 }\end{array}$ & $\begin{array}{c}\text { Acinetobacter } \\
\text { spp. }^{a}\end{array}$ & $\begin{array}{c}\text { Pseudomonas } \\
\text { aeruginosa } \\
\text { NCIB 8295 }\end{array}$ & $\begin{array}{c}\text { Brevibacterium } \\
\text { linens } \\
\text { ATCC 9174 }\end{array}$ \\
\hline $\begin{array}{l}\text { Pyruvate dehydrogenase } \\
\text { Stimulation by AMP }\end{array}$ & $+b$ & + & - & - \\
$\begin{array}{l}\text { Citrate synthase } \\
\text { Inhibition by NADH } \\
\text { Reactivation by AMP } \\
\text { Molecular size }\end{array}$ & + & + & + & - \\
$\begin{array}{l}\text { Isocitrate dehydrogenase } \\
\text { Stimulation by AMP } \\
\alpha-\text { Ketoglutarate dehydrogenase } \\
\text { Stimulation by AMP }\end{array}$ & + & Large & Large & Small \\
$\begin{array}{c}\text { Succinate thiokinase } \\
\text { Apparent } K_{m} \text { for ADP }\end{array}$ & + & + & - & - \\
\hline
\end{tabular}

${ }^{a}$ Three strains, Acinetobacter lwoffi NCTC 5867; A. lwoffi strain 4B; Acinetobacter anitratus NCTC 8102.

$b$ Symbols: +, positive response; -, no response. 
TABLE 2. Characterization of Brevibacterium leucinophagum ATCC 13809 and comparison with Acinetobacter phenon 2 of Thornley.

\begin{tabular}{|c|c|c|c|}
\hline \multirow[b]{2}{*}{ Characteristic } & \multicolumn{2}{|c|}{ Brevibacterium leucinophagum ATCC 13809} & \multirow{2}{*}{$\begin{array}{c}\text { Acinetobacter phenon } \\
2 \text { of } \\
\text { Thornley (8) }\end{array}$} \\
\hline & Present study & Kinney and Werkman (4) & \\
\hline $\begin{array}{l}\text { Colonial morphology } \\
\text { (nutrient agar) }\end{array}$ & \multicolumn{2}{|c|}{$\begin{array}{l}\text { Small (1-2 mm diam) white to buff-colored } \\
\text { colonies, iridescent by reflected light }\end{array}$} & Opaque colonies \\
\hline Cell morphology & $\begin{array}{l}\text { Gram-variable } \\
\text { coccoid rods }\end{array}$ & $\begin{array}{l}\text { Gram-positive coccoid } \\
\text { rods becoming negative } \\
\text { after } 12-16 \mathrm{~h}\end{array}$ & $\begin{array}{l}\text { Gram-variable } \\
\text { coccoid rods }\end{array}$ \\
\hline Motility & $-{ }^{a}$ & - & - \\
\hline Growth at: & & & \\
\hline $\begin{array}{l}10 \mathrm{C} \\
30 \mathrm{C}\end{array}$ & $\begin{array}{l}+ \\
+\end{array}$ & $\begin{array}{l}+ \\
+\end{array}$ & $\dot{t}$ \\
\hline $37 \mathrm{C}$ & + & + & + \\
\hline $45 \mathrm{C}$ & - & - & $\cdot$ \\
\hline Oxidase & - & • & - \\
\hline Catalase & + & $\cdot$ & + \\
\hline $\begin{array}{l}\text { Fermentation of glucose } \\
\text { (acid/gas) }\end{array}$ & - & - & - \\
\hline $\begin{array}{l}\text { Oxidative acid production from: } \\
\text { Arabinose }\end{array}$ & + & • & + \\
\hline Fructose & - & - & - \\
\hline Galactose & + & - & + \\
\hline Glucose & + & + & + \\
\hline Glycerol & - & - & - \\
\hline Lactose & + & - & + \\
\hline Maltose & - & - & $\cdot$ \\
\hline Mannitol & - & - & $\cdot$ \\
\hline Mannose & + & - & - \\
\hline Raffinose & - & - & • \\
\hline Salicin & - & - & - \\
\hline Sorbitol & - & - & - \\
\hline Sucrose & - & - & - \\
\hline Xylose & + & $t^{b}$ & + \\
\hline Methyl red & - & - & - \\
\hline Acetyl methyl carbinol & - & - & - \\
\hline Utilization of: & & & \\
\hline Acetate & + & + & - \\
\hline Citrate & + & + & + \\
\hline$\alpha$-Ketoglutarate & + & + & - \\
\hline Malate & + & + & - \\
\hline Succinate & + & + & - \\
\hline Leucine & + & + & - \\
\hline $\mathrm{NO}_{3}$ reduction & - & - & - \\
\hline $\mathrm{NH}_{3}$ from peptone & - & - & $\cdot$ \\
\hline Urease & $+^{c}$ & - & - \\
\hline Gelatin liquefaction & - & - & - \\
\hline Cellulose & - & - & - \\
\hline Casein & - & - & - \\
\hline Starch & - & - & - \\
\hline Indole production & - & - & - \\
\hline $\begin{array}{l}\text { Penicillin sensitivity } \\
\text { ( } 5 \text { iu disks) }\end{array}$ & - & - & - \\
\hline
\end{tabular}

${ }^{a}$ Symbols: + , positive; - , negative; $\cdot$, not done.

$b$ Kinney and Werkman found that the ability to produce acid oxidatively from xylose was lost after subculturing.

${ }^{c} \mathrm{NH}_{3}$ produced from urea only after 7 to 10 days of incubation at $30 \mathrm{C}$. 


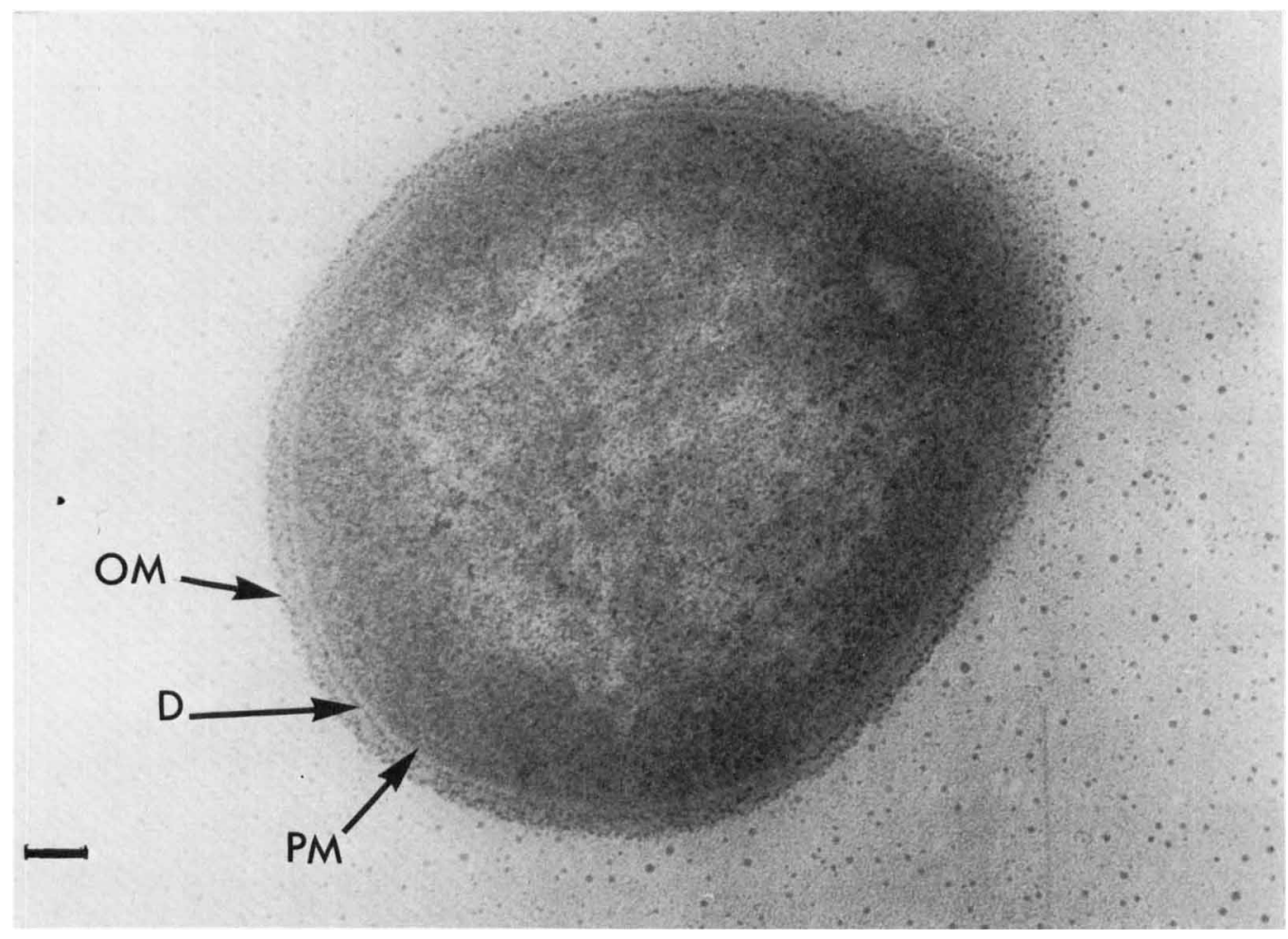

FIG. 1. ATCC 13809 , section through cell; $\times 55,000$. Abbreviations: OM, outer membrane of cell wall; $D$, dense intermediate layer of cell wall; $P M$, plasma membrane. The scale mark represents $0.1 \mathrm{~nm}$.

Achromobacter by Tulecke, Orenski, Taggart, and Colavito (9) as A. liquefaciens, but further studies on this organism suggested that it was gram positive (8). Studies on the citrate synthase enzyme agreed with these findings (3). In most cases, electron micrographs of sections of the cell wall resolve equivocal Gram stain reactions. However, in Haemophilus vaginalis not only is the interpretation of the Gram stain the subject of controversy, but also electron micrographs of thin sections of the cell wall are interpreted differently by different workers. Reyn, Birch-Anderson, and Lapage (6) reported a cell wall structure typical of gram-positive bacteria whereas the results of Criswell, Stenback, Black, and Gardner (1) led them to suggest that the cell wall is of the gram-negative type.

The ease with which the activity of citrate synthase can be assayed and its molecular size determined in crude bacterial extracts makes it an ideal test for resolving taxonomic difficulties in bacteria which possess the enzymes of the tricarboxylic acid cycle and which give equivocal results with the Gram stain. With gram-negative bacteria, further information pertinent to their taxonomic grouping can be obtained from the study of other tricarboxylic acid cycle enzymes. These tests are far simpler and quicker to carry out than electron micrographs of thin sections of the cell wall.

In conclusion, enzyme studies on $B$, leucinophagum ATCC 13809, the type strain of this species, indicate that this bacterium is a gram-negative organism. These observations are supported by electron microscopy and penicillin sensitivity. The results of physiological and biochemical tests, together with the multipoint control of the tricarboxylic acid cycle, suggest that $B$. leucinophagum may be better placed in the genus Acinetobacter. Furthermore, the results listed in Table 2 indicate a close relationship of this organism to Acinetobacter phenon 2 of Thornley (8).

\section{ACKNOWLEDGMENTS}

We thank Janet $\mathrm{K}$. Hewson and John Watkins for skilled technical assistance. We are also indebted to Margaret Thornley for confirmation of the interpretation of electron micrographs. This work was supported, in part, by the Science Research Council (Grant B/SR/80658). 


\section{REPRINT REQUESTS}

Address reprint requests to: Dr. Dorothy Jones, MRC Microbial Systematics Unit, Adrian Building, Leicester University, University Road, Leicester LE1 7RH, England.

\section{LITERATURE CITED}

1. Criswell, B. S., W. A. Stenback, S. H. Black, and H. L. Gardner. 1972. Fine structure of Haemophilus vaginalis. J. Bacteriol. 109:930-932.

2. Glauert, A. M., and M. J. Thornley. 1966. Glutaraldehyde fixation of gram-negative bacteria. J. Roy. Microbiol. Soc. 85:449-453.

3. Jones, D., and P. D. J. Weitzman. 1971. Taxonomic significance of citrate synthase. J. Gen. Microbiol. 69:xi.

4. Kinney, R. W., and C. H. Werkman. 1960. Brevibacterium leucinophagum spec. nov. Int. Bull. Bacteriol. Nomen. Taxon. 10:213-217.

5. Parker, M. G., and P. D. J. Weitzman. 1970. Regulation of NADP-linked isocitrate dehydrogenase activity in Acinetobacter. FEBS Lett. 7:324-326.

6. Reyn, A., A. Birch-Anderson, and S. P. Lapage. 1966. An electron microscope study of thin sections of Haemophilus vaginalis (Gardner and Dukes) and some possibly related species. Can. J. Microbiol. 12:1125-1136.

7. Reynolds, E. S. 1963. The use of lead citrate at high $\mathrm{pH}$ as an electron-opaque stain in electron microscopy. J. Cell. Biol. 17:208-212.

8. Thornley, M. J. 1967. A taxonomic study of Acinetobacter and related genera. J. Gen. Microbiol. 49:211-257.

9. Tulecke, W., S. W. Orenski, R. Taggart, and L. Colavito. 1965. Isolation of an organism resembling Achromobacter liquefaciens. J. Bacteriol. 89:905-906.

10. Weitzman, P. D. J. 1969. Polarographic assay for malate synthase and citrate synthase, p. 365-368. In J. M. Lowenstein (ed.), Methods in enzymology, vol. 13. Academic Press Inc., New York.

11. Weitzman, P. D. J. 1972. Regulation of $\alpha$-ketoglutarate dehydrogenase activity in Acinetobacter. FEBS Lett. 22:323-326.

12. Weitzman, P. D. J., and P. Dunmore. 1969. Citrate synthases: allosteric regulation and molecular size. Biochim. Biophys. Acta 171:198-200.

13. Weitzman, P. D. J., and D. Jones. 1968. Regulation of citrate synthase and microbial taxonomy. Nature (London) 219:270-272. 